\title{
EchoGéo
}

29 | 2014

The Political Ecology of Conservation and

Development Territories

\section{Contentious Territorial Alliances: Coalition Politics and Struggles over Urban Development in Pikine, Senegal}

Nicole C. List

(2) OpenEdition

Journals

Electronic version

URL: https://journals.openedition.org/echogeo/13938

DOI: 10.4000/echogeo.13938

ISSN: 1963-1197

Publisher

Pôle de recherche pour l'organisation et la diffusion de l'information géographique (CNRS UMR 8586)

Electronic reference

Nicole C. List, "Contentious Territorial Alliances: Coalition Politics and Struggles over Urban Development in Pikine, Senegal", EchoGéo [Online], 29 | 2014, Online since 06 November 2014, connection on 31 July 2021. URL: http://journals.openedition.org/echogeo/13938 ; DOI: https:// doi.org/10.4000/echogeo.13938

This text was automatically generated on 31 July 2021.

EchoGéo est mis à disposition selon les termes de la licence Creative Commons Attribution - Pas d'Utilisation Commerciale - Pas de Modification 4.0 International (CC BY-NC-ND) 


\section{Contentious Territorial Alliances: Coalition Politics and Struggles over Urban Development in Pikine, Senegal}

Nicole C. List

\section{Introduction}

1 Cities in the global South are increasingly embroiled in contentious struggles over the right to use, exchange, and manage city spaces (Appadurai, 2001; Bayat, 2000; Chatterjee, 2004; Holston, 2008; Murphy, 2004). Crucial to this body of research is how these urban struggles are producing new territorial strategies (Jonas \& Ward, 2007) and relationships between urban residents and spaces, fundamentally reconfiguring territories of urban governance, capital accumulation, and identity (Goldman, 2011; Hsing, 2010; Roy, 2003; Roy, 2011; Simone, 2004; Yiftachel, 2009). While much of this growing literature on urban territoriality examines struggles over housing, this article sheds light on how equally contentious struggles over the development of urban farmland in Senegal's Dakar Region also inform theoretical work on the political ecology of urban territorial projects. This article thus draws upon research in political ecology that examines how various actors invest in social relations to access, control, and manage land rights (Berry, 1989; Ribot \& Peluso, 2003) that are embedded within larger struggles over territory (Bobrow-Strain, 2007; Carney \& Watts, 1990; Lund, 2008; Neumann, 2002; Peluso, 1992).

2 The ethnographic research ${ }^{1}$ for this article was conducted in Pikine -a rapidly urbanizing city located roughly fifteen kilometers from Senegal's capital city Dakarand examines recent conflicts over how to develop one of the Dakar Region's few remaining pockets of green space. Within recent years, conflicts in the zone studied for this article have erupted over whether farmland should be used to increase urban food 
security, produce horticultural exports managed by agribusiness entrepreneurs, or converted into new housing estates or roads. I argue that these conflicts over how to develop urban farmland draw attention to new ways of practicing politics and larger struggles over who can claim to speak for the state.

This article specifically examines how various public and private actors advocate for urban development projects. I argue that these actors are breaking with older forms of urban governance and increasingly forming what I call 'territorial alliances' that compete with one another to advance their respective urban development projects. I consequently argue that these alliances draw upon spatial strategies to advance their alliance's urban development goals in an effort to consolidate authority over a given zone and profit from their respective urban development projects. These conflicts and territorial alliances emerge from Senegal's current political moment, and signal a new way of practicing urban politics in the wake of structural adjustment, Senegal's 1996 decentralization reforms, rapid rates of urbanization, and rampant land speculation in Dakar.

4 Territory -which I argue here is produced through actors' spatial strategies to govern urban political, economic, and environmental relations- thus figures centrally in understanding contemporary struggles over the development of Dakar's urban farmland. My research thus draws upon Lefebvrian $(2007 ; 2008 ; 2009)$ understandings of space and territory, arguing that Dakar's frontier (Roitman, 2005; Tsing, 2005) for urban development is produced through the configuration of various overlapping and intertwined territorial strategies (Agnew, 1994; Ballvé, 2012; Moore, 2005; Mbembe, 2000).

5 In describing the complex terrain in which these territorial alliances work, my research showcases ethnographies of two distinct -albeit interlinked- episodes of contention ${ }^{2}$ (McAdam et al., 2001) that have played out since 1997 over the development of a 60 hectare tract of urban farmland in Pikine. These ethnographies describe how various coalitions draw from diverse -and competing- spatial strategies to advance their respective territorial projects. Moreover, the ethnographies call attention to significant diversity and differentiation within state territorial strategies, disrupting notions that the Senegalese state has been able to present a unified strategy to recentralize natural resource management in urban settings. Lastly, in reading the outcomes of these conflicts between territorial alliances this article argues this new way of practicing urban politics is actively transforming the cadastre, property rights, and landscapes of built infrastructure in urban Senegal.

\section{Debates on Urban Politics in Pikine}

Academic and popular accounts of Pikine frequently characterize the city as the quintessential home to Senegal's urban slum population that suffers from high crime rates, skyrocketing unemployment, densely populated housing conditions with poor access to public services, and devastating seasonal flooding. While many residents are currently attempting to rebrand Dakar's infamous banlieue (suburb) as a bon-lieu (good place), the predominant negative framings of Pikine life in terms of environmental chaos and economic disorder underscore how the urban inequality produced within Pikine -and between Pikine and Dakar- during colonialism still bears its imprint in Senegal's collective imagination and material landscapes (Sow, 1982). 
7 Originally home to a handful of traditional Lebu ${ }^{3}$ villages, Pikine began its rapid transformation into one of Senegal's largest and most densely populated cities in 1952 when public sanitation fears collided with increases in informal housing settlements, high rates of urban migration, and downtown Dakar's post-WWII construction boom (Betts, 1971; Vernière, 1977). Residents displaced from Dakar's informal housing settlements were provided with plots of land to build housing in Pikine. Lebu elite with autochthonous property rights in Pikine also sold landholdings surrounding their traditional villages en masse, often to rural migrants and residents displaced from Dakar who had sold their housing plots in Pikine's formal neighborhoods (Vernière, 1977). Pikine grew faster than any other city in Africa during these formative years (Salem, 1998), and to this day Pikine commands high rates of demographic growth (Simone, 2003).

8 Faced with such rapid urbanization and inadequate access to public finances, debates concerning how post/colonial governments have sought to govern and provide residents access to public services have figured centrally in research conducted in Pikine. Verniere's $(1973 ; 1977)$ research on Pikine, which traces the transformation of the city from the early 1950s until the mid-1970s, argues that the newly independent Senegalese state largely abandoned Pikine populations. Subsequent analyses critique such descriptions of the central state's disengagement in Pikine, drawing attention to investments in roads, schools, health clinics, and water fountains made by the central state (Navarro, 1988). Moreover, Salem (1992; 1998) describes how various Senegalese state actors fostered urban clientelist relations by providing public services to Pikine neighborhoods that were able to mobilize significant levels of support for Senegal's dominant political party.

Scholars writing in the wake of Senegal's 1996 decentralization reforms have increasingly focused on how political decentralization is creating new social relations between local governments and residents. This research acknowledges the continued significance of traditional authorities -whose political work is largely underestimated by Verniere and Salem- and emphasizes how political decentralization reforms have produced new political networks between traditional authorities, local government officials, and associational life that extend beyond the neighborhood clientelist relations outlined by Salem (Abdoul, 2002, 2005; Simone, 2003, 2004). Nonetheless, the role of central state government actors -who figure prominently in Verniere's and Salem's accounts of Pikine politics- largely disappear from these recent analyses of urban governance in Pikine.

10 By downplaying the roles of central state actors, this research underplays the new and complex ways that politics practiced by central state bureaucrats and politicians are also woven into urban political life. In doing so, it fails to fully interrogate how local politics in Senegal have been transformed by broader political and economic forces (Mohan \& Stokke, 2000), of which structural adjustment programs, Senegal's 1996 decentralization reforms, and President Wade's regime (2000-2012) figure centrally. This article thus situates this study of current urban politics within a growing body of literature characterizing Senegal's transition towards neoliberalism and Wade's presidency in terms of rampant urbanization and land speculation, increased institutional disorganization, worsening corruption, and escalating social inequality (Diop, 2004; Diop, 2013a, 2013b; Gaye, 2010). My analysis of conflicts over the development of urban farmland in the following sections examines how a large variety 
of actors are forming territorial alliances -including elected local/central government officials, government bureaucrats, Senegal's various police forces, associations, and I/ NGOs- to lobby for and advance their territorial strategies.

\section{Historical Context for Current Territorial Conflicts over Pikine Farmland}

11 Located on the fringes of several of Pikine's oldest neighborhoods -spanning the administrative districts of Pikine North and Pikine West- land conflicts in the zone examined for this study were historically comprised of border disputes and struggles over land rights between autochthonous Lebu landowners and farmers who had rented, bought, or been gifted land held by previous Lebu owners. While smallholder farmers in this zone were summarily denied formal property rights, land transactions in Pikine became increasingly common after the implementation of Senegal's 1964 land law (Salem 1998; Vernière 1977). Rampant land transactions continued during Senegal's various droughts during the 1970 s and 1980s, when inadequate access to water, migration-related land pressures, and the development of Pikine's industrial and fishing sectors led many landowners to sell their landholdings. Moreover, many farmers who were unable or unwilling to farm year-round sold their fields because they were increasingly unable to defend land claims during land disputes prompted by this burgeoning land market.

For instance, one autochthonous landowner described a conflict in Pikine North in which an autochthonous landowner's (Landowner 1) field was claimed and later sold by another land user (Landowner 2). After Landowner 2 had farmed Landowner 1's field for ten years, a dispute broke out when Landowner 2 planted trees and staked ownership rights to the land. The matter was then referred to the police and local courts. Landowner 2 was able to create a territorial alliance by drawing upon political connections to win his case and dispossess Landowner 1 of his farmland, as Landowner 1 had been unable to build territorial alliances.

During this period, many farmers without autochthonous land rights were afraid that Pikine's land market and concomitant land conflicts would transform their zone into something similar to the informal housing settlements that dominate scholarly and popular writing on Pikine. One of the largest and most influential farmer associations in Pikine, PROVANIA, was initially founded in 1991 by various farmers who had migrated from Dakar or surrounding regions (and thus did not hold autochthonous land rights) who organized to protect land they had purchased from expropriation and land sales- by autochthonous landowners. After these farmers created PROVANIA, conflicts with the autochthonous landowners decreased. The association developed a territorial strategy to preserve land in the zone for farmland by purchasing land from willing Lebu sellers in adjacent fields until autochthonous landownership in the zone was concentrated in a few pockets of land and various isolated fields surrounded predominantly by landowners and farmers without autochthonous rights.

The first major dispute that erupted in the zone after the creation of PROVANIA was thus not between Lebus and farmers without autochthonous rights, but instead began in 1997 when agribusiness entrepreneurs used connections with elite government officials in President Abdou Diouf's regime -including garnering the support of the Prime Minister- to obtain a long-term lease for land used by Pikine smallholder 
farmers for an export-oriented floriculture project. After numerous court orders were sent to expropriate Pikine farmers' land, the farmers were able to stall their eviction in 2000 by organizing large protests to confront bulldozers and police; voicing their dispute over popular radio stations; engaging a leading Lebu lawyer, politician, and scholar of land rights to defend their claim in court; and mobilizing the support of various Pikine mayors, local traditional authorities, and I/NGOs.

This initial struggle served as a watershed moment in conflicts over urban farmland in Pikine. First, it marked a shift towards conflict engaged between competing territorial alliances, as opposed to conflicts over smaller tracts of farmland between individual landowners and users able to form territorial alliances, as described above. This conflict also opened the floodgate for subsequent land conflicts over large tracts of Pikine farmland. Since 2000, farmer associations in this zone have been continuously involved in land conflicts as various actors seek to carve up their land for a slew of urban development projects. The two conflicts outlined in the following sections describe farmers' struggles to curtail efforts by land developers and a host of government actors that seek to build middle-class and elite housing estates on Pikine farmland. These disputes take place in Pikine West and Pikine North on land that was initially targeted for the export-oriented floriculture project outlined above. The conflicts described not only unfold at different moments, but farmers confront distinct -albeit interlinked- political, economic, and ecological geographies. My analysis of these two contentious episodes thus relies upon an examination of how dramatically divergent political geographies and dispute outcomes are produced by spatially differentiated territorial strategies -in terms of how territorial alliances are brokered, co-opted, de/mobilized, coerced, radicalized, or internationalized (Tilly \& Tarrow, 2007).

\section{Pikine West}

Open conflict over the transformation of eight hectares of farmland into a housing estate in Pikine West began shortly after the landmark dispute described above. In 2002, Pikine West elected a new district mayor ${ }^{4}$ who began to broker a territorial alliance to transform the disputed land into a middle-class and elite housing estate. Local bureaucrats in Pikine informed me that the district mayor signed a protocole d'accorde with the agribusiness entrepreneurs to gain access to their claims to land. The mayor also began to organize a series of secretive meetings with bureaucrats in the Ministry of Land and Taxes and the Ministry of Urbanism, private land developers, and select landowners to develop the disputed terrain.

The district mayor's attempts to spearhead the construction of a middle-class and elite housing project was a central component of his territorial governing strategies. Research on Senegal's current wave of 'speculative urbanism' (Goldman 2011) has pivoted around increased investments in massive infrastructural projects since President Wade's election in 2000 (Galvan 2001; Melly 2013). Often working in tandem with central government actors and private real estate developers, many local urban government officials have also sought to strengthen their urban governance regimes by facilitating the construction of new housing projects. Local governments rely upon a quota system to distribute serviced housing plots in new housing estates to bolster political and/or administrative support. In Pikine, roughly 25 percent of serviced plots 
can potentially be used to provide land -and financing- to party militants and various government administrators in exchange for their political and/or administrative support. ${ }^{5}$

Housing projects that follow Pikine's official quota system thus rely upon strategic territorial alliances between landowners willing to sell their land, private housing developers and cartographers, local government officials (including elected district/ city mayors, their council members, and local land management bureaucrats), and central government officials (mostly bureaucrats in the Ministry of Urbanism and the Ministry of Land and Taxes). However, the housing project undertaken in Pikine West did not follow these guidelines. Instead, the district mayor attempted to take more than his allowed quota of housing plots by providing inadequate housing plot compensation to landowners whose plots had been expropriated. He also attempted to avoid paying housing plot quota requirements by 'hiding' the project from the city Mayor's office and various central government officials. The district mayor thus promised to provide housing plots directly to government actors -in the Ministry of Urbanism, the Ministry of Land and Taxes, and various police forces- who helped provide coercive force to dispossess landowners resistant to the housing project and secure necessary paperwork without following Pikine's quota system.

Conflicts over the new housing project reached their climax between 2006-7 when the district mayor and his chosen private housing developer sent a team of bulldozers and local police to expropriate farmers' land. While several farmers I spoke with noted how they met -publicly and privately- with the district Mayor to discuss the project before the bulldozers arrived, many farmers were not privy to these negotiations and instead described how the bulldozers arrived in their fields without warning. In the end, the district mayor's coalition was able to divide landowners and renters into two clans: landowners who felt that they had no choice but to support the new housing estate, and a combination of landowners and renters who harshly critiqued and mobilized against the project. Landowners who supported the project did so for three main reasons: $1 /$ many landowners -especially those renting out land- were convinced that selling their land was more profitable than farming, 2/ some landowners land claims were shared by family members who didn't farm and wanted to profit from high land prices, and $3 /$ none of the landowners held formal land titles and they were afraid that the mayor's alliances or subsequent conflicts would expropriate their land without providing farmers with any compensation. Various landowners -including the leaders of Pikine West's farmers' association- were thus co-opted by the district mayor's territorial alliance and negotiated to exchange their land rights for serviced housing plots.

19 The district mayor and his territorial alliance was unable to co-opt renters -who were not compensated at all- and landowners who argued that the land deal didn't follow Pikine's quota system or adequately compensate them for their land rights. Farmers resistant to the new housing project mobilized to create a new farmer association (as the older group had disbanded after the exit of leaders who supported the housing project), stood in front of bulldozers, fought with local and national police, filed complaints in court, and voiced their concerns over the radio. Farmers also knocked on doors of powerful politicians who had the ear of President Abdoulaye Wade, who eventually sent a special commission to investigate farmers' complaints and involved Pikine's city-wide mayor in the conflict. 

When other district mayors and powerful politicians heard about the project they negotiated to receive housing plots in exchange for their consent. For example, the city Mayor negotiated for the provision of housing plots for disgruntled landowners. He also offered to compensate some dispossessed landowners and renters for the loss of the investments they had made on their land by providing them with serviced plots in another housing subdivision in Pikine's peri-urban fringes. In exchange for these concessions, the remaining landowners and renters were co-opted within the district mayor's territorial alliance and agreed to relinquish their land rights.

This final reconfiguration of territorial alliances proved problematic for Pikine West's district mayor. While the housing estate was eventually built, the number of housing plots he had promised exceeded the total number of plots created. One of the leaders in Pikine West's defunct farmers' association recalled a grim conversation when the district mayor informed him that he would be receiving three -instead of eighthousing plots in exchange for his work initially securing the consent of many Pikine farmers. When describing this conversation, the ex-leader noted how the mayor remarked how he had really helped advance the housing project, but that the mayor was overwhelmed with requests for housing plots by the prefect, governor, district mayors, and ministers who heard about the project in this sector. Various individuals who bought land at the project's conception also took the district mayor to court when they didn't receive the plots they were promised. Finally, the youth football team was also upset when land for the field they had been promised was instead divvied into housing plots. These and various other actors upset about how land for the housing project was distributed complained vociferously during the 2008 local elections. Many residents argue that the district mayor's -and to some extent also the city mayor'sfailed re-election bids were thus due to the public's discontent over their involvement in the Pikine West housing project. This political shift indicates that the territorial alliances that were so crucial in advancing the district mayor's territorial strategies and thus transforming most of Pikine West's farmland into middle-class and elite housing- were ultimately unable to withstand the repercussions of how the shady land deal in Pikine West unfolded.

\section{Pikine North}

Farmer associations had already been active in Pikine North prior to the conflict instigated by horticultural entrepreneurs. As mentioned earlier, the most prominent association, PROVANIA, was largely populated by farmers without autochthonous land rights who developed a territorial strategy of buying farmland from willing autochthonous sellers in order to ensure that their zone would be reserved for urban farming. Moreover, farmers in PROVANIA also brokered strategic alliances with local and government officials and I/NGOs to invest in urban agriculture and demonstrate how urban agriculture in Pikine contributed to the development of Senegal's Dakar Region by providing a significant number of jobs, contributing to regional food security, and safeguarding the local ecosystem. PROVANIA thus worked closely with central government officials in the Ministry of Urbanism drafting plans to safeguard their farmland and the local ecosystem, which resulted in a presidential decree that ostensibly protected farmland in the zone from development. The association also 
brokered alliances with government agencies providing technical assistance to Senegalese farmers, and at one point was working with at least five different I/NGOs on agricultural development projects.

In order to secure their access to treated wastewater, farmers also began to develop strategic alliances in 2004 with I/NGOs, local government authorities in various Pikine mayor offices, the government agency charged with treatment of wastewater, and an international team of academics and Senegalese government employees (in the Ministry of Agriculture and the Ministry of Health). While farmers in nearby zones are able to rely upon hand-dug wells to access water, many of the fields used by PROVANIA farmers stand on higher elevations which means that they are unable to obtain water to irrigate their fields unless they dig costly wells. The initial wastewater project thus brokered a dynamic alliance between a variety of public and private actors to design best practices for wastewater use in agriculture and construct several wastewater treatment basins on PROVANIA farmers' fields. This project was then expanded -with the FAO coordinating funding from the Spanish government- to helped farmers 1/ formally negotiate access to wastewater treated by Senegal's public-private water sanitation authority and 2/provide farmers with water pumps and a vast network of PVC pipes and infrastructure used to distribute treated wastewater to farmers' fields.

While PROVANIA farmers were building international territorial alliances with I/NGOs, various government bureaucrats, and other farmer associations to promote agricultural development projects and secure their claims to land, the agribusiness entrepreneurs who attempted to expropriate farmers' land in 2000 were reconfiguring their territorial alliances and strategies to develop farmland held under their longterm lease. First, the entrepreneurs decided that they would abandon their agricultural endeavors and instead use the land to develop new housing estates. Given that their original attempts to dispossess farmers based on formal land rights obtained through territorial alliances failed, they instead chose to draw upon similar territorial strategies originally practiced by PROVANIA farmers. They began offering to buy farmland from willing sellers; this would allow them to secure pockets of land while co-opting association members and fracturing the territorial authority held by PROVANIA. In 2010 they were able to buy a small tract of farmland from a Lebu landowner and installed a small shop on the property.

These actions produced conflict between the entrepreneurs/housing developers and farmers in the zone, largely because the individual who sold his land initially refused to admit that he had accepted money from the developers. PROVANIA farmers acknowledged that the landowner had the right to sell his field to whomever he wanted, and once it was confirmed that the Lebu landowner had indeed sold his field they dropped the conflict. Yet this small land purchase served as the entry-point to a larger conflict when the housing developers hired a bulldozer to prepare this newly acquired field for a new housing project. Once the field had been leveled, the bulldozer passed by several nearby fields that were serviced by the wastewater project and began bulldozing a field that was not being farmed because it lacked access to irrigated water.

PROVANIA farmers' reaction was to mobilize their alliances with other farmer organizations and local traditional authorities to form a delegation to speak with various government officials. The delegation visited the prefect (who was not in her office), sub-prefect, and city Mayor's office but was unable to uncover which government authority had authorized the developer's activities. It was only after 
meeting with the commissaire of the local police who had sent roughly 20 police to oversee the project that the delegation learned that the prefect had sent a letter asking the police to intervene because local farmers were keeping developers from 'doing their job' and developing the zone. The conflict escalated when farmers began to fight with local policemen. After several hours of what farmers described as a 'violent battle,' the commissaire withdrew his troops arguing that he didn't want to be responsible for any casualties. Over the following days farmers and policemen waited in the fields but the bulldozers and developers never returned. Farmers contend that this was in part because the proprietor of the bulldozer refused to hire out his machine when he heard about farmers' purchases of gas and plans to burn the bulldozer if it returned.

This conflict has been at a standstill since farmers' altercations with local police. Farmers continue to cultivate land in the zone, and it appears that the farmers' territorial alliances with I/NGOs and a variety of government officials are -at least temporarily- proving stronger than the territorial coalitions produced by housing developers. While I/NGO and government officials who have partnered with farmers have largely remained silent during land conflicts, farmers have relied upon material investments by these partners, physical violence and threats of property destruction, and relationships with nearby farmers and traditional authorities to defend their land claims. Contrary to the housing development in Pikine West, housing developers have not been able to co-opt their opposition and quickly absorb government officials aligned with farmers' territorial alliances.

\section{Conclusion}

This article has focused on conflicts over whether Pikine's remaining tracts of farmland should be used for the development of middle-class and elite housing estates or for the development of agricultural projects that ensure food security and employment opportunities for the greater Dakar region. The contentious episodes examined in Pikine West and Pikine North vary significantly from historical land conflicts over urban farmland in Pikine, as disputes between landowners and land users over individual fields are progressively being replaced by larger conflicts involving a wide range of public and private actors. The main thrust of this article thus examines how recent contentious struggles over the development of new housing estates are increasingly relying upon new forms of territorial alliances to shape the development trajectories of Pikine's few remaining tracts of farmland.

In describing the increased reliance of territorial alliances in Pikine, this article sheds new light on the literature examining 'the right to the city' and concomitant struggles to use, exchange, and manage urban spaces. Much of the current literature on the 'right to the city' examines housing politics. By focusing on struggles that pivot around farming and housing, this article brings this urban politics literature into conversation with research in political ecology examining questions of access (Ribot \& Peluso, 2003) rather than rights- to urban land. I have thus argued how landowners and users in Pikine strategically invest in social relations (Berry, 1989) through the formation of territorial alliances in order to secure access to urban land.

These territorial alliances are characterized by coalitions formed between farmer associations, traditional authorities, housing developers, local/central government officials, and I/NGOs. Yet these competitive territorial alliances are notable not only for 
their flexibility, but also for their fragility. Territorial alliances are constantly being negotiated and reconfigured throughout the duration of each conflict highlighted in this article. Farmer associations' struggles with local police in Pikine North stalled the conflict by weakening the territorial alliance formed between the police, prefect and housing developer. President Wade and the city mayor in Pikine were later included in the territorial alliance coordinated by the Pikine West mayor in order to effectively disband territorial alliances produced by the farmer groups that were against the new housing project. Territorial alliances thus operate in a state of flux and are de/ constructed through a wide variety of territorial strategies.

31 In studying these strategies, this article draws attention to significant spatial variations in how various actors' practice contentious politics in two different administrative districts within one of Senegal's largest cities. These districts are home to distinct albeit interlinked- political, economic, and ecological geographies that have greatly influenced how contention between territorial alliances played out during land struggles. The initial territorial alliance produced to negotiate Pikine West's new housing estate was first brokered by the district mayor, who was able to co-opt key members of farmer groups and continually include various local and central government officials within his coalition. The territorial alliance produced by housing developers in Pikine North was unable to replicate mechanisms and processes undertaken by the district Mayor in Pikine West. While developers were able to form alliances with key central government officials and co-opt one farmer (who sold them his land), they were unable to build additional alliances to strengthen their land claims with local and high-level central government officials. Moreover, they were unable to co-opt the farmers' association or convince its leaders to defect. Instead, the organization relied upon international concerns over food security and the zone's water-poor geography to build strong alliances with I/NGOs, local/central government officials, other farmer associations and traditional authorities to defend their land claims. Farmers in Pikine North were also able to escalate tensions and puncture holes within territorial alliances coordinated by housing developers by threatening property destruction and collective violence against local police. Thus, while certain territorial strategies were present in struggles in both Pikine North and Pikine West (e.g., brokerage and mobilization of territorial alliances that frequently rely upon coercive force), there are also important differences in the ways in which various coalitions advocated for their territorial project (e.g., territorial alliances' ability to rely upon international relations, escalate tactics, and/or co-opt and demobilize key coalitions) (Tilly \& Tarrow, 2007).

Studying the similarities and variations in how these various territorial alliances are constructed in Pikine North and Pikine West also sheds light on the increasingly significant roles played by local government officials (Abdoul, 2005; Simone, 2004). Senegal's 1996 decentralization reforms -combined with the rise of speculative land markets and high rates of demographic growth- have thus helped shape new interactions between local governments, farmer associations, and I/NGOs. Yet this by no means indicates that the central government is no longer a central actor in negotiations over how to develop Pikine's remaining farmland. Instead, this article examines the new relations formed between associational life, central government officials, and decentralized local governmental officials. 


\section{BIBLIOGRAPHY}

Abdoul M., 2002. The Production of the City and Urban Informalities: The Borough of Thiaroyesur-Mer in the City of Pikine, Senegal. In O. Enwezor et al., eds. Under siege, four African cities, Freetown, Johannesburg, Kinshasa, Lagos: Documenta 11, Platform 4. Ostfildern-Ruit, Hatje Cantz, p. 337-358.

Abdoul M., 2005. Urban development and urban informalities: Pikine, Senegal. In A. M. Simone \& A. Abouhani, eds. Urban Africa: changing contours of survival in the city. London; New York; New York: Zed Books in association with CODESRIA, Dakar, Senegal ; distributed exclusively in the United States by Palgrave Macmillan, p 235-260.

Agnew J., 1994. The Territorial Trap: The Geographical Assumptions of International Relations Theory. Review of International Political Economy, 1(1), p. 53.

Ballvé T, 2012. Everyday state formation: Territory, decentralization, and the Narco Landgrab in Colombia. Environment and Planning D: Society and Space, 30(4), p. 603-622.

Bayat A., 2000. From "Dangerous Classes" to "Quiet Rebels": Politics of the Urban Subaltern in the Global South. International Sociology, 15(3), p. 533-557.

Berry S., 1989. Social Institutions and Access to Resources. Africa: Journal of the International African Institute, 59(1), p. 41-55.

Betts R., 1971. The Establishment of the Medina in Dakar, Senegal, 1914. Africa, 41(2), p. 143.

Bobrow-Strain A., 2007. Intimate enemies: landowners, power, and violence in Chiapas. Durham, Duke University Press.

Carney J. \& Watts M., 1990. Manufacturing Dissent: Work, Gender and the Politics of Meaning in a Peasant Society. Africa, 60(2), p. 207-241.

Diop M., 2004. Gouverner le Sénégal : entre ajustement structurel et développement durable. Paris: Karthala.

Diop M.C., 2013a. Le Sénégal sous Abdoulaye Wade : le Sopi à l'épreuve du pouvoir. Paris/Dakar, Karthala/CRES.

Diop M.C., 2013b. Sénégal (2000-2012) : Les institutions et politiques publiques à l'épreuve d'une gouvernance libérale, Paris, Karthala.

Galvan D.C., 2001. Political Turnover and Social Change in Senegal. Journal of Democracy, 12(3), p. 51-62.

Gaye M., 2010. Le Sénégal sous Abdoulaye Wade : banqueroute, corruption et liberticide. Paris, L'Harmattan.

Geschiere, P., 2009. The perils of belonging: autochthony, citizenship, and exclusion in Africa and Europe. Chicago, University of Chicago Press.

Goldman M., 2011. Speculating on the Next World City. In A. Roy \& A. Ong, eds, Worlding cities: Asian experiments and the art of being global. Chichester, West Sussex, Malden, MA, Wiley-Blackwell, p. 229-258.

Holston J., 2008. Insurgent citizenship : disjunctions of democracy and modernity in Brazil. Princeton, Princeton University Press. 
Hsing Y., 2010. The great urban transformation politics of land and property in China. Oxford, Oxford University Press.

Jonas A.E. \& Ward K., 2007. Introduction to a Debate on City-Regions: New Geographies of Governance, Democracy and Social Reproduction. IJUR International Journal of Urban and Regional Research, 31(1), p. 169-178.

Lefebvre H., 2009. State, space, world : selected essays. Minneapolis, University of Minnesota Press.

Lefebvre H., 2007. The production of space [Nachdr.], Malden, Blackwell.

Lefebvre H., 2008. The urban revolution [Nachdr.], Minneapolis, University of Minnesota Press.

Lund C., 2008. Local politics and the dynamics of property in Africa. New York: Cambridge University Press.

Mbembe J., 2000. At the Edge of the World: Boundaries, Territoriality, and Sovereignty in Africa. Public Culture, 12(1), p. 259-284.

McAdam D., Tarrow, S. \& Tilly, C., 2001. Dynamics of contention, Cambridge, New York, Cambridge University Press.

Melly C., 2013. Ethnography on the road: infrastructural vision and the unruly present in contemporary Dakar. Africa, 83(3), p. 385-402.

Mohan G. \& Stokke K., 2000. Participatory development empowerment: the dangers of localism. Third world quarterly : journal of emerging area., 21(2).

Moore D., 2005. Suffering for territory : race, place, and power in Zimbabwe. Durham, Duke University Press.

Murphy E., 2004. Developing Sustainable Peripheries: The Limits of Citizenship in Guatemala City. Latin American Perspectives, 31(6), p. 48-68.

Navarro R., 1988. Irregularité urbaine et invention de la ville africaine au Cap-Vert. Tiers-Monde, 29(116), p. 1101-1118.

Neumann R.P., 2002. Imposing wilderness: struggles over livelihood and nature preservation in Africa. Berkeley, London, University of California Press.

Peluso N.L., 1992. Rich forests, poor people resource control and resistance in Java. Berkeley, University of California Press.

Ribot, J., Agrawal, A. \& Larson, A., 2006. Recentralizing While Decentralizing: How National Governments Reappropriate Forest Resources. World development., 34(11), p. 1864.

Ribot J. \& Peluso N., 2003. A Theory of Access. Rural sociology., 68(2), p. 153.

Roitman, J., 2005. Fiscal disobedience : an anthropology of economic regulation in Central Africa. Princeton N.J., Princeton University Press.

Roy A., 2003. City requiem, Calcutta : gender and the politics of poverty. Minneapolis, University of Minnesota Press.

Roy A., 2011. The Blockade of the World-Class City: Dialectial Images of Indian Urbanism. In A. Roy \& A. Ong, eds, Worlding Experiences: Asian Experiments and the Art of Being Global. Blackwell.

Salem G., 1992. Crise urbaine et contrôle social à Pikine: bornes-fontaines et clientélisme. Politique africaine Politique africaine, (45), p. 21-38.

Salem G., 1998. La santé dans la ville : géographie d'un petit espace dense : Pikine (Sénégal). Paris, Karthala. 
Simone A., 2004. For the city yet to come : changing African life in four cities. Durham, Duke University Press.

Simone A., 2003. Reaching the Larger World: New Forms of Social Collaboration in Pikine, Senegal. Africa: Journal of the International African Institute, 73(2), p. 226-250.

Sow F., 1982. Lire la ville africaine contemporaine: Pikine (Senegal). [Dakar]: Institut fondamental d'Afrique noire, Université de Dakar.

Sylla, A., 1992. Le peuple Lebou de la presqu'ile du Cap-Vert. [Dakar], Nouvelles éditions africaines du Sénégal.

Tilly C. \& Tarrow S.G., 2007. Contentious politics. Boulder, Colo., Paradigm Publishers.

Tsing, A., 2005. Friction : an ethnography of global connection. Princeton N.J., Princeton University Press.

Vernière M., 1977. Volontarisme d'État et spontanéisme populaire dans l'urbanisation du Tiers-monde: formation et évolution des banlieues dakaroises : le cas de Dagoudane Pikine. Paris, Bibliothèque nationale.

Vernière M., 1973. Pikine, « ville nouvelle » de Dakar, un cas de pseudo-urbanisation. Espace géographique, 2(2), p. 107-126.

Yiftachel O., 2009. Theoretical Notes On 'Gray Cities': the Coming of Urban Apartheid? Planning Theory, 8(1), p. 88-100.

\section{NOTES}

1. Fieldwork for this article was conducted between 2011-2013, and is part of a larger comparative study of contentious land politics in Senegal's Dakar Region.

2. Various scholars have noted that the field of contentious politics loosely integrates spatial analyses (Martin \& Miller, 2003; Sewell, 2001; Tilly, 2003). While various scholars have begun to examine dynamics of contention in relation to Lefebvrian understandings of how space and social life are mutually constituted (Cresswell, 1996; Hart, 2002; Mitchell, 2003; Wolford, 2003), spatial analysis remains an interesting lacuna within research on contentious politics.

3. The Lebu were the first inhabitants of the Dakar Region (Sylla, 1992). Throughout this article I refer to the Lebu as the autochthonous population, drawing from Geshiere's (2009) work tracing understandings of autochthony to notions of being "from the soil" and an authentic belonging to a specific territory (p. 2).

4. The organization of local government in large urban areas in Senegal (e.g., Dakar, Pikine, Rufisque) is very elaborate, with the city mayor charged with executive and administrative duties for municipality's entire territory, which is broken down into districts (or arrondissements) that are headed by district mayors.

5. Pikine's quota system distributes serviced housing plots as follows: those selling land rights retain $65 \%$ of plots, central government administration receive $10 \%$, local government obtains $10 \%, 10 \%$ is used to pay for work preparing land for the housing project, and the remaining $5 \%$ finances work conducted by private housing developers and cartographers. 


\section{ABSTRACTS}

Contentious territorial struggles over how to manage and develop city spaces figure centrally in research on urban governance in the global South. Drawing from ethnographic fieldwork in Pikine, a rapidly urbanizing city in Senegal's Dakar Region, this article examines how Dakar's political geography is being transformed by the configuration of multiple, overlapping territorial strategies for the development of urban farmland in one of the region's few remaining pockets of green spaces. Through analysis of two spatially distinct -albeit interlinked- episodes of conflict over the development of middle-class and elite housing projects on Pikine farmland, I argue that various public and private actors -including farmers, traditional authorities, housing developers, and local/central government officials- are breaking with older forms of urban governance and forming what I call "territorial alliances" to stake land claims and advance urban development projects. These territorial alliances are producing new political relations between local/central government actors and associational life while also dramatically transforming the cadastre, property rights, and landscapes of public infrastructure in urban Senegal.

Les litiges territoriaux qui concernent la gestion et l'aménagement des espaces urbains occupent un rôle central dans la recherche sur la gouvernance urbaine dans les pays du Sud. A partir du travail de terrain réalisé par l'auteur à Pikine, une ville qui s'est rapidement urbanisée dans la région de Dakar (Sénégal), cet article montre comment la géographie politique de Dakar se transforme par les reconfigurations spatiales engendrées par des stratégies territoriales multiples et superposées visant au développement d'une agriculture urbaine là où des poches d'espaces verts sont préservées. L'analyse de 2 cas de conflits -différents mais interconnectés- à propos de l'aménagement de terres agricoles urbaines en vue de lotissements pour la classe moyenne et les élites permet à l'auteur d'affirmer que des acteurs publics et privés - notamment des producteurs, des autorités traditionnelles, des promoteurs immobiliers, et des officiels dans les gouvernements locaux/centraux- abandonnent les anciennes formes de gouvernance au profit «d'alliances territoriales» afin de promouvoir leurs propres projets de développement urbain. Ces alliances territoriales conduisent à de nouvelles relations entre les membres des gouvernements locaux/centraux et la société civile et ont une incidence sur le cadastre, les droits de propriété et les infrastructures publique du Sénégal urbain.

\section{INDEX}

Mots-clés: territoire, agriculture urbaine, habitat, urbanisation, propriété, Sénégal

Keywords: territory, urban agriculture, housing, urbanization, property, Senegal

\section{AUTHOR}

\section{NICOLE C. LIST}

Nicole C. List nicole.list@berkeley.edu, is PhD Candidate, Geography Department, University of California, Berkeley. 